Article

\title{
Spectroscopic Studies of Amino Acid Ionic Liquid-Supported Schiff Bases
}

\section{Paula Ossowicz ${ }^{1}$, Ewa Janus ${ }^{2}$, Grzegorz Schroeder $^{3}$ and Zbigniew Rozwadowski ${ }^{1, *}$}

1 Department of Inorganic and Analytical Chemistry, West Pomeranian University of Technology, Szczecin, Al. Piastów 42, Szczecin 71-065, Poland; E-Mail: paulaossowicz@o2.pl

2 Department of Organic Chemical Technology, West Pomeranian University of Technology, Szczecin, ul. Pułaskiego 10, Szczecin 70-332, Poland; E-Mail: ejanus@zut.edu.pl

3 Faculty of Chemistry, A. Mickiewicz University, ul. Umultowska 89b, Poznań 61-614, Poland; E-Mail: schroede@amu.edu.pl

* Author to whom correspondence should be addressed; E-Mail: zroz@zut.edu.pl;

Tel.: +48-91-449-4553; Fax: +48-91-449-4636.

Received: 22 February 2013; in revised form: 8 April 2013 / Accepted: 17 April 2013 /

Published: 29 April 2013

\begin{abstract}
Amino acid ionic liquid-supported Schiff bases, derivatives of salicylaldehyde and various amino acids (L-threonine, L-valine, L-leucine, L-isoleucine and L-histidine) have been investigated by means of various spectroscopic techniques (NMR, UV-Vis, IR, MS) and deuterium isotope effects on ${ }^{13} \mathrm{C}$-NMR chemical shifts. The results have shown that in all studied amino acid ionic liquid-supported Schiff bases (except the L-histidine derivative) a proton transfer equilibrium exists and the presence of the $\mathrm{COO}^{-}$group stabilizes the proton transferred $\mathrm{NH}$-form.
\end{abstract}

Keywords: amino acid ionic liquids; Schiff bases; deuterium isotope effect; intramolecular hydrogen bond

\section{Introduction}

Ionic liquids (ILs) which are composed solely of ions [1] and are liquid at ambient temperature [2] have been widely studied as replacements for volatile organic solvents in various reactions. A particularly attractive advantage of ionic liquids is their negligible vapor pressure, which results in reduced air emissions, non-flammability and non-explosiveness [1-3]. In addition, other physical 
properties of ILs such as their polarity, hydrophobicity, hydrogen-bond basicity, viscosity and solvation interactions with organic and inorganic compounds can be carefully modulated through the proper selection of cations and anions [4-8]. Recently, much attention has been paid to a new generation of ionic liquids originating from natural raw materials such as amino acids. Amino acid ionic liquids are an alternative to traditional ionic liquids, based solely on petrochemical raw materials. Amino Acid Ionic Liquids (AAILs) derived from biorenewable raw materials, have increased biocompatibility of the ionic liquid, expressed by greater ability to biodegrade in the environment, and also have lower toxicity (both ecotoxicity and cytotoxicity) $[9,10]$.

Organic salts of amino acid Schiff bases can be excellent candidates for ionic liquids because of a large selection of aldehydes, amino acids, presence or lack of intramolecular hydrogen bonds as well as various cations which can strongly influence the acquired properties of ionic liquids [11,12]. It is well known that Schiff bases derived from amino acids and ortho-hydroxy aldehydes show biological activity and are widely applied as ligands of complexes used as enantioselective catalysts. In various biologically important reactions, Schiff bases are formed as intermediate products [13]. The presence of intramolecular hydrogen bond is essential for their enzymatic function and the proton transfer process from oxygen to nitrogen atom is the first step of the catalytic cycle [14].

Moreover, the possibility of use of the amino acid ionic liquid-supported Schiff bases as the chiral solvents as well as ligands of the catalysts makes this class of compounds especially promising. Ionic liquid-supported Schiff bases, derivatives of 1-(2-aminoethyl)-3-methylimidazolium hexafluorophosphate and aromatic aldehydes, were investigated as ligands and as solvents for the Pd-catalyzed Suzuki-Miyaura coupling reaction, with good to excellent yields of biaryls being obtained $[15,16]$.

Most authors working on amino acid ionic liquids have been interested in their synthesis and some physical properties, e.g., polarity, thermal stability or miscibility. A new trend in ionic liquid research concerns more detailed studies of factors that can strongly affect their properties, e.g., interactions with solvents in Diels-Alder reactions. The use of NMR data has been proposed for prediction of the reaction selectivity $[17,18]$.

Previously we have studied the proton transfer equilibrium in chloroform solution of tetrabutylammonium salts of amino acid Schiff bases, derivatives of 2-hydroxynaphthaldehyde [19] and lithium salts of these Schiff bases in DMSO [20] and water [21] by means of NMR spectroscopy. In this paper we extend our studies to other techniques (IR, UV-Vis, MS) and investigate derivatives of salicylaldehyde, which can be considered as a new group of amino acid ionic liquids. We focus our attention on tetrabutylammonium salts of Schiff base derivatives of salicylaldehyde and different amino acids. Proton transfer equilibria (Figure 1) have been also studied because they are crucial for investigation of their properties. Organic salts of amino acid Schiff bases, derivatives of 2-hydroxyaldehyde and substituted salicylaldehydes exist mainly in pure proton transferred form [19]. Selection of the amino acids (L-threonine, L-leucine, L-isoleucine, L-histidine) and salicylaldehyde can influence the position of the proton in intramolecular hydrogen bonds and hence can allow us to obtain amino acid ionic liquids with the desired required position of the proton transfer equilibrium. 
Figure 1. Proton transfer equilibrium in Schiff bases.<smiles>[X]c1ccc2c(c1)C=[N+]([R])NO2</smiles>

$\mathrm{OH}$-form

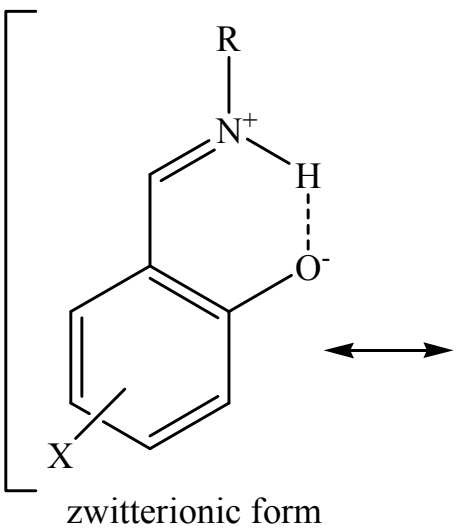

$\mathrm{NH}$-form<smiles>[X]C(=O)C=Cc1cccc(=O)cc1[R]</smiles>

keto form

In proton transfer equilibrium studies, the measurements of deuterium isotope effects on chemical shift are especially effective. This method allows detection of the presence of proton transfer equilibria and determination of the respective mole fractions of tautomers. Measurements of deuterium isotope effects on chemical shifts can be performed as a one tube experiment for a partially deuterated sample. The position of the proton transfer equilibrium in Schiff bases was determined on the basis of deuterium isotope effects on ${ }^{13} \mathrm{C}-\mathrm{NMR}$ chemical shifts [22]. The deuterium isotope effects were measured as differences between the ${ }^{13} \mathrm{C}$ signals in the spectra of non- deuterated and deuterated species: ${ }^{\mathrm{n}} \Delta \mathrm{C}(\mathrm{D})=\delta \mathrm{C}(\mathrm{H})-\delta \mathrm{C}(\mathrm{D})$.

\section{Results and Discussion}

\subsection{NMR, IR and UV-Vis}

The ${ }^{1} \mathrm{H}$ - and ${ }^{13} \mathrm{C}-\mathrm{NMR}$ chemical shifts for all positions and the whole range of temperatures (295, 270, 250 and $230 \mathrm{~K}$ ) for compounds $\mathbf{1}-\mathbf{5}$ (Figure 2) in $\mathrm{CDCl}_{3}$ and DMSO solutions are given in Table 1. Some of the data for compound 3 in $\mathrm{CDCl}_{3}$ have been taken from [19]. ${ }^{1} \mathrm{H}$ chemical shifts in $\mathrm{CDCl}_{3}$ for compound 3 at position H-3 and H-6 were corrected to those from reference [19].

Figure 2. Amino acid ionic liquids supported Schiff bases 1-5.

(1) $\mathrm{R}=\mathrm{CH}(\mathrm{OH}) \mathrm{CH}_{3}$

(2) $\mathrm{R}=\mathrm{CH}\left(\mathrm{CH}_{3}\right)_{2}$

(3) $\mathrm{R}=\mathrm{CH}_{2} \mathrm{CH}\left(\mathrm{CH}_{3}\right)_{2}$

(4) $\mathrm{R}=\mathrm{CH}\left(\mathrm{CH}_{3}\right) \mathrm{CH}_{2} \mathrm{CH}_{3}$

(5) $\mathrm{R}=$<smiles>CCc1cnc[nH]1</smiles><smiles>[R]C(N=Cc1ccccc1O)C(=O)[O-]</smiles><smiles>CCCC[N+](CCCC)(CCCC)CCCC</smiles> 
Table 1. ${ }^{1} \mathrm{H}$ and ${ }^{13} \mathrm{C}$ chemical shifts (ppm), deuterium isotope effects (ppb) and ${ }^{3} J_{(\mathrm{NH}, \mathrm{H})}$ coupling constants $(\mathrm{Hz})$ of compounds $\mathbf{1}-\mathbf{5}$ in $\mathrm{CDCl} \mathrm{l}_{3}$ and DMSO.

\begin{tabular}{|c|c|c|c|c|c|c|c|c|c|c|c|c|c|c|}
\hline \multirow[t]{2}{*}{ Comp. } & \multirow{2}{*}{$\begin{array}{c}\mathbf{T} \\
(\mathbf{K})\end{array}$} & & & \multicolumn{10}{|c|}{ Position } & \multirow[t]{2}{*}{${ }^{3} J_{(\mathrm{NH} . \mathrm{H})}$} \\
\hline & & & & 1 & 2 & 3 & 4 & 5 & 6 & $\alpha$ & 21 & $1^{\prime}$ & Others & \\
\hline \multirow{14}{*}{$\begin{array}{l}\text { (1) } \\
\text { Sal-L- } \\
\text { Thr }\end{array}$} & 295 & $\mathrm{CDCl}_{3}$ & $\begin{array}{l}\delta \mathrm{H} \\
(\mathrm{ppm})\end{array}$ & - & 14.41 & 6.85 & $\sim 7.25$ & 6.78 & $\sim 7.25$ & 8.45 & - & 4.16 & $3.92 ; 3.18 ; 1.56 ; 1.37 ; 1.20 ; 0.95$ & \multirow[t]{3}{*}{ n.o. } \\
\hline & & & $\begin{array}{l}\delta \mathrm{C} \\
(\mathrm{ppm})\end{array}$ & 119.01 & 165.20 & 117.46 & 132.06 & 117.59 & 131.50 & 163.14 & 173.97 & 76.09 & $68.13 ; 58.54 ; 23.86 ; 19.67 ; 19.11 ; 13.65$ & \\
\hline & & & $\begin{array}{l}\Delta \mathrm{C}(\mathrm{D}) \\
(\mathrm{ppb})\end{array}$ & n.o. & 136 & n.o. & n.o. & n.o. & n.o. & 451 & n.o. & -174 & & \\
\hline & 270 & $\mathrm{CDCl}_{3}$ & $\begin{array}{l}\mathrm{H} \\
(\mathrm{ppm})\end{array}$ & - & 14.49 & 6.85 & $\sim 7.3$ & 6.80 & $\sim 7.3$ & 8.46 & - & 4.17 & $3.94 ; 3.16 ; 1.54 ; 1.36 ; 1.21 ; 0.95$ & \multirow[t]{3}{*}{ n.o. } \\
\hline & & & $\begin{array}{l}\delta \mathrm{C} \\
(\mathrm{ppm})\end{array}$ & 118.81 & 165.27 & 117.36 & 132.12 & 117.69 & 131.48 & 162.85 & 174.07 & 75.93 & $68.00 ; 58.23 ; 23.67 ; 19.59 ; 19.05 ; 13.69$ & \\
\hline & & & $\begin{array}{l}\mathrm{CC}(\mathrm{D}) \\
(\mathrm{ppb})\end{array}$ & -155 & 174 & -88 & 57 & 152 & -72 & 527 & 77 & -178 & & \\
\hline & 250 & $\mathrm{CDCl}_{3}$ & $\begin{array}{l}\delta \mathrm{H} \\
(\mathrm{ppm})\end{array}$ & - & 14.55 & 6.87 & $\sim 7.3$ & 6.83 & $\sim 7.3$ & 8.46 & - & 4.18 & $3.96 ; 3.16 ; 1.53 ; 1.34 ; 1.23 ; 0.96$ & \multirow[t]{3}{*}{ n.o. } \\
\hline & & & $\begin{array}{l}\delta \mathrm{C} \\
(\mathrm{ppm})\end{array}$ & 118.65 & 165.36 & 117.30 & 132.20 & 117.79 & 131.49 & 162.62 & 174.18 & 75.78 & $67.91 ; 58.00 ; 23.52 ; 19.54 ; 19.01 ; 13.75$ & \\
\hline & & & $\begin{array}{l}\Delta \mathrm{C}(\mathrm{D}) \\
(\mathrm{ppb})\end{array}$ & -145 & 174 & -86 & 67 & 139 & -64 & 535 & 74 & -178 & & \\
\hline & 230 & $\mathrm{CDCl}_{3}$ & $\begin{array}{l}\delta \mathrm{H} \\
(\mathrm{ppm})\end{array}$ & - & 14.62 & 6.89 & 7.36 & 6.85 & 7.31 & 8.47 & - & 4.18 & $3.99 ; 3.14 ; 1.53 ; 1.33 ; 1.23 ; 0.96$ & \multirow[t]{3}{*}{ n.o. } \\
\hline & & & $\begin{array}{l}\delta \mathrm{C} \\
(\mathrm{ppm})\end{array}$ & 118.48 & 165.41 & 117.26 & 132.30 & 117.88 & 131.49 & 162.41 & 174.28 & 75.57 & $67.81 ; 57.77 ; 23.38 ; 19.50 ; 18.97 ; 13.81$ & \\
\hline & & & $\begin{array}{l}\Delta \mathrm{C}(\mathrm{D}) \\
(\mathrm{ppb})\end{array}$ & 136 & 174 & -86 & 68 & 149 & -73 & 540 & 83 & -235 & & \\
\hline & 295 & DMSO & $\begin{array}{l}\mathrm{H} \\
(\mathrm{ppm})\end{array}$ & - & 14.32 & 6.76 & 7.24 & 6.74 & 7.34 & 8.37 & - & 3.81 & $3.60 ; 3.15 ; 1.55 ; 1.30 ; 1.02 ; 0.92$ & \multirow[t]{2}{*}{ n.o. } \\
\hline & & & $\begin{array}{l}\delta \mathrm{C} \\
(\mathrm{ppm})\end{array}$ & 118.26 & 164.49 & 116.65 & 132.06 & 117.40 & 131.51 & 163.68 & 170.95 & 75.10 & $67.35 ; 57.38 ; 22.95 ; 19.44 ; 19.11 ; 13.40$ & \\
\hline
\end{tabular}


Table 1. Cont.

\begin{tabular}{|c|c|c|c|c|c|c|c|c|c|c|c|c|c|c|}
\hline \multirow[t]{2}{*}{ Comp. } & \multirow{2}{*}{$\begin{array}{c}\mathbf{T} \\
(\mathbf{K}) \\
\end{array}$} & & & \multicolumn{10}{|c|}{ Position } & \multirow[t]{2}{*}{${ }^{3} J_{(\text {NH.H) }}$} \\
\hline & & & & 1 & 2 & 3 & 4 & 5 & 6 & $\alpha$ & 21 & 11 & Others & \\
\hline \multirow{14}{*}{$\begin{array}{l}(2) \\
\text { Sal-L- } \\
\text { Val }^{\mathrm{a}}\end{array}$} & 295 & $\mathrm{CDCl}_{3}$ & $\begin{array}{l}\delta \mathrm{H} \\
(\mathrm{ppm})\end{array}$ & - & 14.75 & 6.79 & 7.23 & 6.66 & 7.17 & 8.21 & - & 3.71 & $3.24 ; 1.57 ; 1.35 ; 1.00 ; 0.94$ & \multirow[t]{3}{*}{ n.o. } \\
\hline & & & $\begin{array}{l}\delta \mathrm{C} \\
(\mathrm{ppm})\end{array}$ & 117.85 & 167.22 & 119.11 & 132.89 & 115.95 & 131.85 & 163.39 & 173.44 & 79.11 & $58.57 ; 31.45 ; 23.94 ; 19.70 ; 18.34 ; 13.67$ & \\
\hline & & & $\begin{array}{l}\Delta \mathrm{C}(\mathrm{D}) \\
(\mathrm{ppb})\end{array}$ & n.o. & n.o. & n.o. & n.o. & n.o. & n.o. & n.o. & n.o. & n.o. & & \\
\hline & $270^{\mathrm{b}}$ & $\mathrm{CDCl}_{3}$ & $\begin{array}{l}\delta \mathrm{H} \\
(\mathrm{ppm})\end{array}$ & - & 14.90 & 6.79 & 7.24 & 6.65 & 7.18 & 8.17 & - & 3.73 & $3.24 ; 1.57 ; 1.35 ; 0.99 ; 0.94$ & \multirow[t]{3}{*}{ br. } \\
\hline & & & $\begin{array}{l}\delta \mathrm{C} \\
(\mathrm{ppm})\end{array}$ & 117.38 & 168.07 & 119.46 & 133.21 & 115.61 & 131.93 & 163.34 & 173.28 & 78.58 & $58.28 ; 31.32 ; 23.77 ; 19.62 ; 18.14 ; 13.72$ & \\
\hline & & & $\begin{array}{l}\Delta \mathrm{C}(\mathrm{D}) \\
(\mathrm{ppb})\end{array}$ & n.o. & $74^{c}$ & n.o. & -48 & -51 & -135 & 269 & n.o. & n.o. & & \\
\hline & 250 & $\mathrm{CDCl}_{3}$ & $\begin{array}{l}\delta \mathrm{H} \\
(\mathrm{ppm})\end{array}$ & - & 14.89 & 6.80 & 7.28 & 6.67 & 7.20 & 8.16 & - & 3.76 & $3.20 ; 1.55 ; 1.33 ; 1.00 ; 0.93$ & \multirow[t]{3}{*}{6.1} \\
\hline & & & $\begin{array}{l}\delta \mathrm{C} \\
(\mathrm{ppm})\end{array}$ & 117.07 & 168.38 & 119.58 & 133.46 & 115.55 & 132.04 & 163.51 & 173.43 & 78.06 & $\begin{array}{c}58.00 ; 31.21 ; 23.58 ; 19.56 ; 18.45 ; 17.65 ; \\
13.83\end{array}$ & \\
\hline & & & $\begin{array}{l}\Delta \mathrm{C}(\mathrm{D}) \\
(\mathrm{ppb})\end{array}$ & 29 & -73 & n.o. & -75 & -105 & -156 & 271 & n.o. & n.o. & & \\
\hline & 230 & $\mathrm{CDCl}_{3}$ & $\begin{array}{l}\delta \mathrm{H} \\
(\mathrm{ppm})\end{array}$ & - & 15.00 & 6.80 & 7.31 & 6.67 & 7.22 & 8.14 & - & 3.81 & $3.20 ; 1.54 ; 1.31 ; 1.00 ; 0.94$ & \multirow[t]{3}{*}{7.1} \\
\hline & & & $\begin{array}{l}\delta \mathrm{C} \\
(\mathrm{ppm})\end{array}$ & 116.61 & 169.66 & 120.09 & 133.91 & 115.19 & 132.18 & 163.52 & 173.35 & 77.4 & $\begin{array}{c}57.78 ; 31.09 ; 23.43 ; 19.52 ; 18.45 ; 17.65 ; \\
13.83\end{array}$ & \\
\hline & & & $\begin{array}{l}\Delta \mathrm{C}(\mathrm{D}) \\
(\mathrm{ppb})\end{array}$ & 80 & br. & br. & -183 & -149 & -118 & 283 & n.o. & n.o. & & \\
\hline & 295 & DMSO & $\begin{array}{l}\delta \mathrm{H} \\
(\mathrm{ppm})\end{array}$ & - & 14.54 & 6.68 & 7.29 & 6.62 & 7.21 & 8.28 & - & 3.44 & $\begin{array}{c}3.15 ; 2.26 ; 1.55 ; 1.29 ; 1.04 ; 0.92 ; 0.84 \\
0.82\end{array}$ & \multirow[t]{2}{*}{ n.o. } \\
\hline & & & $\begin{array}{l}\delta \mathrm{C} \\
(\mathrm{ppm})\end{array}$ & 117.68 & 166.36 & 118.49 & 132.56 & 115.55 & 131.85 & 163.35 & 170.63 & 77.98 & $\begin{array}{c}57.50 ; 56.01 ; 30.86 ; 23.08 ; 20.27 ; 19.23 ; \\
18.58 ; 18.11 ; 13.52 \\
\end{array}$ & \\
\hline
\end{tabular}


Table 1. Cont.

\begin{tabular}{|c|c|c|c|c|c|c|c|c|c|c|c|c|c|c|}
\hline \multirow{2}{*}{ Comp. } & \multirow{2}{*}{$\begin{array}{c}\mathbf{T} \\
(\mathbf{K})\end{array}$} & & & \multicolumn{10}{|c|}{ Position } & \multirow{2}{*}{${ }^{3} \boldsymbol{J}_{(\mathrm{NH} . \mathrm{H})}$} \\
\hline & & & & 1 & 2 & 3 & 4 & 5 & 6 & $\alpha$ & 21 & $1^{\prime}$ & Others & \\
\hline \multirow{18}{*}{$\begin{array}{l}\text { (3) } \\
\text { Sal-L- } \\
\text { Leu }\end{array}$} & 295 & $\mathrm{CDCl}_{3}$ & $\begin{array}{l}\delta \mathrm{H} \\
(\mathrm{ppm})\end{array}$ & - & 14.76 & 6.79 & 7.22 & 6.68 & 7.18 & 8.32 & - & 4.02 & $\begin{array}{c}3.23 ; 1.91 ; 1.68 ; 1.57 ; 1.37 ; 0.96 ; 0.92 \\
0.89\end{array}$ & \multirow[t]{3}{*}{ n.o. } \\
\hline & & & $\begin{array}{l}\delta \mathrm{C} \\
(\mathrm{ppm})\end{array}$ & 118.20 & 166.11 & 118.73 & 132.60 & 116.34 & 131.84 & 163.14 & 174.21 & 71.25 & $\begin{array}{c}58.59 ; 43.09 ; 25.03 ; 23.93 ; 21.50 ; 19.71 \\
18.49 ; 13.67\end{array}$ & \\
\hline & & & $\begin{array}{l}\Delta C(D) \\
(\mathrm{ppb})\end{array}$ & n.o. & n.o. & n.o. & n.o. & n.o. & n.o. & n.o. & n.o. & n.o. & & \\
\hline & 270 & $\mathrm{CDCl}_{3}$ & $\begin{array}{l}\mathrm{H} \\
(\mathrm{ppm})\end{array}$ & - & 14.83 & 6.80 & 7.25 & 6.69 & 7.20 & 8.30 & - & 4.03 & $\begin{array}{c}3.20 ; 1.91 ; 1.63 ; 1.56 ; 1.35 ; 0.95 ; 0.91 \\
0.88\end{array}$ & \multirow[t]{3}{*}{ n.o. } \\
\hline & & & $\begin{array}{l}\delta \mathrm{C} \\
(\mathrm{ppm})\end{array}$ & 117.83 & 166.36 & 118.85 & 132.83 & 116.25 & 131.90 & 163.22 & 174.30 & 70.85 & & \\
\hline & & & $\begin{array}{l}\Delta \mathrm{C}(\mathrm{D}) \\
(\mathrm{ppb})\end{array}$ & n.o. & 248 & n.o. & n.o. & -47 & -103 & 248 & n.o. & -113 & $\begin{array}{c}58.24 ; 42.77 ; 24.83 ; 23.71 ; 21.18 ; 19.63 ; \\
18.50 ; 13.73\end{array}$ & \\
\hline & 250 & $\mathrm{CDCl}_{3}$ & $\begin{array}{l}\mathrm{H} \\
(\mathrm{ppm})\end{array}$ & - & 14.84 & 6.81 & $\sim 7.3$ & 6.71 & 7.22 & 8.30 & - & 4.05 & $3.17 ; 1.92 ; 1.54 ; 1.32 ; 0.95 ; 0.88$ & \multirow[t]{3}{*}{3.3} \\
\hline & & & $\begin{array}{l}\delta \mathrm{C} \\
(\mathrm{ppm})\end{array}$ & 117.20 & 166.87 & 119.00 & 133.04 & 116.10 & 131.96 & 163.56 & $\mathbf{1 7 4 . 3 7}$ & 70.35 & $\begin{array}{c}58.00 ; 42.51 ; 24.66 ; 23.71 ; 20.92 ; 19.57 \\
18.46 ; 13.77 \\
\end{array}$ & \\
\hline & & & $\begin{array}{l}\Delta \mathrm{C}(\mathrm{D}) \\
(\mathrm{ppb})\end{array}$ & n.o. & 198 & n.o. & n.o. & -44 & -121 & 259 & n.o. & -104 & & \\
\hline & 230 & $\mathrm{CDCl}_{3}$ & $\begin{array}{l}\mathrm{H} \\
(\mathrm{ppm})\end{array}$ & - & 14.95 & 6.82 & 7.30 & 6.72 & 7.24 & 8.27 & - & 4.06 & $3.18 ; 1.94 ; 1.54 ; 1.33 ; 0.95 ; 0.91 ; 0.87$ & \multirow[t]{3}{*}{7.3} \\
\hline & & & $\begin{array}{l}\mathrm{C} \\
(\mathrm{ppm})\end{array}$ & 117.19 & 167.24 & 119.23 & 133.31 & 116.03 & 131.93 & 163.68 & $\mathbf{1 7 4 . 4 5}$ & 69.88 & $\begin{array}{c}57.78 ; 42.24 ; 24.51 ; 23.76 ; 20.64 ; 19.53 ; \\
13.84\end{array}$ & \\
\hline & & & $\begin{array}{l}\Delta \mathrm{C}(\mathrm{D}) \\
(\mathrm{ppb})\end{array}$ & n.o. & 146 & n.o. & n.o. & n.o. & 869 & 256 & n.o. & -76 & & \\
\hline & 350 & DMSO & $\begin{array}{l}\delta \mathrm{H} \\
(\mathrm{ppm})\end{array}$ & - & 14.20 & 6.69 & 7.19 & 6.64 & 7.26 & 8.35 & - & 3.72 & $3.20 ; 1.78 ; 1.61 ; 1.34 ; 0.94 ; 0.88 ; 0.86$ & \multirow[t]{6}{*}{ n.o. } \\
\hline & & & $\begin{array}{l}\delta \mathrm{C} \\
(\mathrm{ppm})\end{array}$ & 118.59 & 166.95 & 118.64 & 132.52 & 116.12 & 132.0 & 162.95 & 171.26 & 71.13 & $\begin{array}{c}58.53 ; 43.89 ; 25.37 ; 23.75 ; 22.44 ; \\
19.69 ; 13.73\end{array}$ & \\
\hline & 330 & & $\begin{array}{l}\delta \mathrm{H} \\
(\mathrm{ppm})\end{array}$ & - & 14.4 & 6.69 & 7.20 & 6.64 & 7.28 & 8.35 & - & 3.70 & $3.19 ; 1.75 ; 1.61 ; 1.32 ; 0.93 ; 0.88 ; 0.86$ & \\
\hline & & & $\begin{array}{l}\mathrm{C} \\
(\mathrm{ppm})\end{array}$ & 118.51 & 166.14 & 118.62 & 132.61 & 116.17 & 132.06 & 163.07 & 171.39 & 71.10 & $\begin{array}{c}58.31 ; 43.79 ; 25.31 ; 23.74 ; 22.35 ; \\
19.68 ; 13.82 \\
\end{array}$ & \\
\hline & 295 & & $\begin{array}{l}\mathrm{H} \\
(\mathrm{ppm})\end{array}$ & - & 14.53 & 6.68 & 7.28 & 6.63 & 7.20 & 8.33 & - & 3.66 & $3.16 ; 1.90 ; 1.55 ; 1.29 ; 0.92 ; 0.86 ; 0.83$ & \\
\hline & & & $\begin{array}{l}\delta \mathrm{C} \\
(\mathrm{ppm})\end{array}$ & 117.70 & 165.73 & 118.15 & 132.25 & 115.59 & 131.63 & 162.69 & 170.81 & 70.33 & $\begin{array}{c}57.37 ; 43.01 ; 24.61 ; 23.28 ; 22.95 ; 21.55 \\
19.10 ; 13.39\end{array}$ & \\
\hline
\end{tabular}


Table 1. Cont.

\begin{tabular}{|c|c|c|c|c|c|c|c|c|c|c|c|c|c|c|}
\hline \multirow[t]{2}{*}{ Comp. } & \multirow{2}{*}{$\begin{array}{c}\mathbf{T} \\
(\mathbf{K}) \\
\end{array}$} & & & \multicolumn{10}{|c|}{ Position } & \multirow[t]{2}{*}{${ }^{3} \boldsymbol{J}_{(\mathrm{NH} . \mathrm{H})}$} \\
\hline & & & & 1 & 2 & 3 & 4 & 5 & 6 & $\alpha$ & 21 & $1^{\prime}$ & Others & \\
\hline \multirow{14}{*}{$\begin{array}{l}(4) \\
\text { Sal-L- } \\
\text { Ile }\end{array}$} & \multirow[t]{3}{*}{295} & \multirow[t]{3}{*}{$\mathrm{CDCl}_{3}$} & $\begin{array}{l}\delta \mathrm{H} \\
(\mathrm{ppm})\end{array}$ & - & 14.81 & 6.79 & 7.23 & 6.64 & 7.16 & 8.18 & - & 3.74 & $\begin{array}{c}3.23 ; 2.87 ; 2.24 ; 1.66 ; 1.56 ; 1.35 ; 1.23 \\
0.97 ; 0.93 ; 0.88\end{array}$ & \multirow[t]{3}{*}{ n.o. } \\
\hline & & & $\begin{array}{l}\delta \mathrm{C} \\
(\mathrm{ppm})\end{array}$ & 117.77 & 167.56 & 119.31 & 133.01 & 115.86 & 131.90 & 163.18 & 173.56 & 78.74 & $\begin{array}{c}58.60 ; 37.95 ; 24.98 ; 23.95 ; 19.72 ; 16.51 ; \\
13.67 ; 11.56\end{array}$ & \\
\hline & & & $\begin{array}{l}\Delta \mathrm{C}(\mathrm{D}) \\
(\mathrm{ppb})\end{array}$ & n.o. & n.o. & n.o. & n.o. & n.o. & n.o. & n.o. & n.o. & n.o. & & \\
\hline & \multirow[t]{3}{*}{270} & \multirow[t]{3}{*}{$\mathrm{CDCl}_{3}$} & $\begin{array}{l}\mathrm{H} \\
(\mathrm{ppm})\end{array}$ & - & 14.89 & 6.78 & 7.24 & 6.65 & 7.18 & 8.16 & - & 3.78 & $\begin{array}{c}3.23 ; 2.27 ; 1.68 ; 1.56 ; 1.33 ; 1.23 ; 1.16 \\
0.96 ; 0.91 ; 0.88\end{array}$ & \multirow[t]{3}{*}{ br. } \\
\hline & & & $\begin{array}{l}\delta \mathrm{C} \\
(\mathrm{ppm})\end{array}$ & 117.31 & 168.24 & 119.55 & 133.30 & 115.60 & 131.96 & 163.24 & 173.52 & 78.28 & $\begin{array}{c}58.24 ; 37.75 ; 24.69 ; 23.73 ; 19.63 ; 16.44 ; \\
13.72 ; 11.61\end{array}$ & \\
\hline & & & $\begin{array}{l}\Delta \mathrm{C}(\mathrm{D}) \\
(\mathrm{ppb})\end{array}$ & n.o. & $-43^{c}$ & -58 & 35 & n.o. & -145 & 254 & n.o. & n.o. & & \\
\hline & \multirow[t]{3}{*}{250} & \multirow[t]{3}{*}{$\mathrm{CDCl}_{3}$} & $\begin{array}{l}\mathrm{HH} \\
(\mathrm{ppm})\end{array}$ & - & 14.94 & 6.79 & 7.27 & 6.66 & 7.19 & 8.14 & - & 3.80 & $\begin{array}{c}3.21 ; 2.28 ; 1.68 ; 1.56 ; 1.30 ; 1.23 ; 1.16 \\
0.95 ; 0.90 ; 0.88\end{array}$ & \multirow[t]{3}{*}{6.0} \\
\hline & & & $\begin{array}{l}\mathrm{CC} \\
(\mathrm{ppm})\end{array}$ & 116.94 & 168.78 & 119.78 & 133.60 & 115.42 & 132.05 & 163.30 & 173.57 & 77.87 & $\begin{array}{c}58.01 ; 37.63 ; 24.44 ; 23.57 ; 19.57 ; 16.38 ; \\
13.77 ; 11.67\end{array}$ & \\
\hline & & & $\begin{array}{l}\Delta \mathrm{C}(\mathrm{D}) \\
(\mathrm{ppb})\end{array}$ & 59 & -41 & -112 & -83 & n.o. & -164 & 276 & n.o. & 101 & & \\
\hline & \multirow[t]{3}{*}{230} & \multirow[t]{3}{*}{$\mathrm{CDCl}_{3}$} & $\begin{array}{l}\delta \mathrm{H} \\
(\mathrm{ppm})\end{array}$ & - & 15.03 & 6.79 & 7.31 & 6.64 & 7.21 & 8.10 & - & 3.85 & $\begin{array}{c}3.22 ; 2.33 ; 1.70 ; 1.55 ; 1.32 ; 1.23 ; 1.17 \\
0.95 ; 0.90 ; 0.88\end{array}$ & \multirow[t]{3}{*}{7.2} \\
\hline & & & $\begin{array}{l}\mathrm{CC} \\
(\mathrm{ppm})\end{array}$ & 116.46 & 169.85 & 120.24 & 134.02 & 115.03 & 132.22 & 163.37 & 173.46 & 77.41 & $\begin{array}{c}57.78 ; 37.49 ; 24.15 ; 23.43 ; 19.54 ; 16.35 ; \\
13.83 ; 11.76 \\
\end{array}$ & \\
\hline & & & $\begin{array}{l}\Delta \mathrm{C}(\mathrm{D}) \\
(\mathrm{ppb})\end{array}$ & 85 & -143 & -150 & -134 & 95 & -158 & 295 & n.o. & ov. & & \\
\hline & \multirow[t]{2}{*}{295} & \multirow[t]{2}{*}{ DMSO } & $\begin{array}{l}\delta \mathrm{H} \\
(\mathrm{ppm})\end{array}$ & - & 14.57 & 6.66 & 7.27 & 6.60 & 7.20 & 8.26 & - & 3.44 & $3.15 ; 1.99 ; 1.50 ; 1.29 ; 1.00 ; 0.93 ; 0.83$ & \\
\hline & & & $\begin{array}{l}\delta \mathrm{C} \\
(\mathrm{ppm})\end{array}$ & 117.56 & 166.83 & 118.67 & 132.58 & 115.27 & 131.86 & 163.05 & 170.24 & 77.37 & $\begin{array}{c}57.49 ; 37.56 ; 24.63 ; 23.06 ; 19.22 ; 16.60 ; \\
13.52 ; 11.67 \\
\end{array}$ & \\
\hline
\end{tabular}


Table 1. Cont.

\begin{tabular}{|c|c|c|c|c|c|c|c|c|c|c|c|c|c|c|}
\hline \multirow[t]{2}{*}{ Comp. } & \multirow{2}{*}{$\begin{array}{c}\mathbf{T} \\
(\mathbf{K})\end{array}$} & & & \multicolumn{10}{|c|}{ Position } & \multirow{2}{*}{${ }^{3} J_{(\mathrm{NH} . \mathrm{H})}$} \\
\hline & & & & 1 & 2 & 3 & 4 & 5 & 6 & $\alpha$ & 21 & $1^{\prime}$ & Others & \\
\hline \multirow{14}{*}{$\begin{array}{l}(5) \\
\text { Sal-L- } \\
\text { His }\end{array}$} & 295 & $\mathrm{CDCl}_{3}$ & $\begin{array}{l}\delta \mathrm{H} \\
(\mathrm{ppm})\end{array}$ & - & 12.33 & 6.63 & $\sim 7.3$ & 6.80 & $\sim 7.3$ & 7.53 & - & 5.19 & $\begin{array}{c}3.75 ; 3.58 ; 3.32 ; 3.14 ; 2.94 ; 1.54 ; \\
1.30 ; 0.92\end{array}$ & \\
\hline & & & $\begin{array}{l}\mathrm{CC} \\
(\mathrm{ppm})\end{array}$ & $\sim 123.7$ & $\sim 157.3$ & 116.22 & $\sim 128.3$ & 118.88 & $\sim 129.6$ & n.o. & n.o. & 58.67 & $58.31 ; \sim 26.45 ; 23.93 ; 19.69 ; 13.67$ & \\
\hline & & & $\begin{array}{l}\Delta \mathrm{C}(\mathrm{D}) \\
(\mathrm{ppb})\end{array}$ & n.o. & n.o. & n.o. & n.o. & n.o. & n.o. & n.o. & n.o. & n.o. & & \\
\hline & 270 & $\mathrm{CDCl}_{3}$ & $\begin{array}{l}\mathrm{H} \\
(\mathrm{ppm})\end{array}$ & - & 12.75 & 6.63 & 7.08 & 6.81 & $\sim 7.3$ & 7.47 & - & 5.20 & $\begin{array}{c}11.82 ; 3.77 ; 3.36 ; 3.09 ; 2.98 ; 1.52 ; 1.26 ; \\
0.91\end{array}$ & \\
\hline & & & $\begin{array}{l}\delta \mathrm{C} \\
(\mathrm{ppm})\end{array}$ & 123.71 & 157.11 & 116.10 & 126.47 & 118.88 & 129.46 & 135.53 & $\mathbf{1 7 5 . 3 5}$ & 59.81 & $58.31 ; 27.34 ; 23.70 ; 19.57 ; 13.69$ & \\
\hline & & & $\begin{array}{l}\Delta \mathrm{C}(\mathrm{D}) \\
(\mathrm{ppb})\end{array}$ & n.o. & n.o. & n.o. & n.o. & n.o. & n.o. & n.o. & n.o. & n.o. & & \\
\hline & 250 & $\mathrm{CDCl}_{3}$ & $\begin{array}{l}\delta \mathrm{H} \\
(\mathrm{ppm})\end{array}$ & - & 12.91 & 6.64 & 7.09 & 6.83 & $\sim 7.3$ & 7.44 & - & 5.19 & $\begin{array}{c}11.87 ; 3.80 ; 3.65 ; 3.40 ; 3.07 ; \sim 3.0 ; 1.51 \\
1.25 ; 0.91\end{array}$ & \\
\hline & & & $\begin{array}{l}\delta \mathrm{C} \\
(\mathrm{ppm})\end{array}$ & 123.74 & 156.87 & 116.05 & 126.21 & 118.89 & 129.47 & 135.10 & 175.60 & 59.64 & $134.87 ; 58.05 ; 27.15 ; 23.55 ; 19.49 ; 13.72$ & \\
\hline & & & $\begin{array}{l}\Delta \mathrm{C}(\mathrm{D}) \\
(\mathrm{ppb})\end{array}$ & 157 & n.o. & n.o. & n.o. & n.o. & $136^{\mathrm{a}}$ & 393 & n.o. & $-88^{a}$ & & \\
\hline & 230 & $\mathrm{CDCl}_{3}$ & $\begin{array}{l}\delta \mathrm{H} \\
(\mathrm{ppm})\end{array}$ & - & 13.06 & 6.65 & 7.11 & 6.85 & $\sim 7.3$ & 7.47 & - & 5.20 & $\begin{array}{c}11.91 ; 3.83 ; 3.67 ; 3.43 ; 3.05 ; 1.51 ; 1.25 ; \\
0.91\end{array}$ & \\
\hline & & & $\begin{array}{l}\mathrm{CC} \\
(\mathrm{ppm})\end{array}$ & 123.58 & 156.82 & 115.98 & 126.16 & 118.88 & 129.38 & 135.01 & $\mathbf{1 7 5 . 6 9}$ & 59.49 & $128.24 ; 57.26 ; 26.94 ; 23.44 ; 19.45 ; 13.77$ & \\
\hline & & & $\begin{array}{l}\Delta \mathrm{C}(\mathrm{D}) \\
(\mathrm{ppb})\end{array}$ & 143 & br. & $-41^{c}$ & $-28^{c}$ & 64 & br. & br. & n.o. & br. & 40 & \\
\hline & 295 & DMSO & $\begin{array}{l}\delta \mathrm{H} \\
(\mathrm{ppm})\end{array}$ & - & 12.1 & 6.61 & 7.06 & 6.74 & 7.19 & 7.30 & - & 5.04 & $\sim 11.6 ; 3.19 ; 3.14 ; \sim 2.9 ; 1.57 ; 1.33 ; 0.96$ & \\
\hline & & & $\begin{array}{l}\delta \mathrm{C} \\
(\mathrm{ppm})\end{array}$ & 124.47 & 157.79 & 116.41 & 127.80 & 118.38 & 129.85 & 133.85 & 172.83 & 58.91 & $\begin{array}{c}136.09 ; 129.85 ; 58.0 ; 26.72 ; 23.57 ; 19.72 ; \\
14.00\end{array}$ & \\
\hline
\end{tabular}

n.o. not observed; br. broad signals; ${ }^{a}$ Data in $\mathrm{CDCl}_{3}$ at 295,250 and $230 \mathrm{~K}$ from reference $[19] ;{ }^{b}$ Data from partly deuterated compound; ${ }^{\mathrm{c}}$ Uncertain value. 
The type of amino acids group usually has a small effect on the positions of the ${ }^{13} \mathrm{C}$ signals assigned to the phenyl ring. The $\mathrm{C}-2$ chemical shift values are the most sensitive to the position of the hydrogen engaged in the intramolecular hydrogen bond and vary in $\mathrm{CDCl}_{3}$ solution at $295 \mathrm{~K}$ from $\delta 165.2$ for the L-treonine derivative up to $\delta 167.6 \mathrm{ppm}$ for that of L-isoleucine. Moreover it increases as the temperature is lowered. The greatest change of up to $\Delta=2.19 \mathrm{ppm}$, was observed for compound $\mathbf{3}$, and the lowest $\Delta=0.19 \mathrm{ppm}$ for the L-threonine derivative (1). Similar effects were observed for other salts of amino acid Schiff bases [19-21]. The type of amino acid had a small influence of the chemical shift of the $\mathrm{C}=\mathrm{O}$ carbon. The chemical shift values of the $\mathrm{C}=\mathrm{O}$ carbon in the compounds studied were similar to those determined for other Schiff bases involving R-substituted salicylaldehydes [19]. For the L-histidine derivative 5 a shielding effect of the imidazole ring was observed for $\mathrm{H}-\alpha$ and $\mathrm{C}-\alpha$. The difference in the chemical shifts of signals $\mathrm{H}-\alpha$ and $\mathrm{C}-\alpha$ for compounds 1-4 and compound 5 (the L-histidine derivative) is $1 \mathrm{ppm}$ for $\mathrm{H}-\alpha$ and about $30 \mathrm{ppm}$ for $\mathrm{C}-\alpha$.

All observed deuterium isotope effects are presented in Table 1. Large positive values of deuterium isotope effects in the range from $c a .250$ up to $c a .550 \mathrm{ppb}$ were found for C- $\alpha$. Negative values were observed for C-6. Both positive and negative values were observed for the other carbons. It is known that the value of deuterium isotope effect on the carbon atom linked to the phenolic group reflects the position of proton in the hydrogen bridge [22,23]. On the basis of the $\Delta \mathrm{C}-2$ (D) vs. mole fraction of the $\mathrm{NH}$-form relationship, it is possible to estimate the position of the equilibrium (Figure 3) in Schiff bases.

Figure 3. Plot of $\Delta \mathrm{C}-2$ (D) vs. mole fraction of the proton transferred NH-form $(\chi)$.

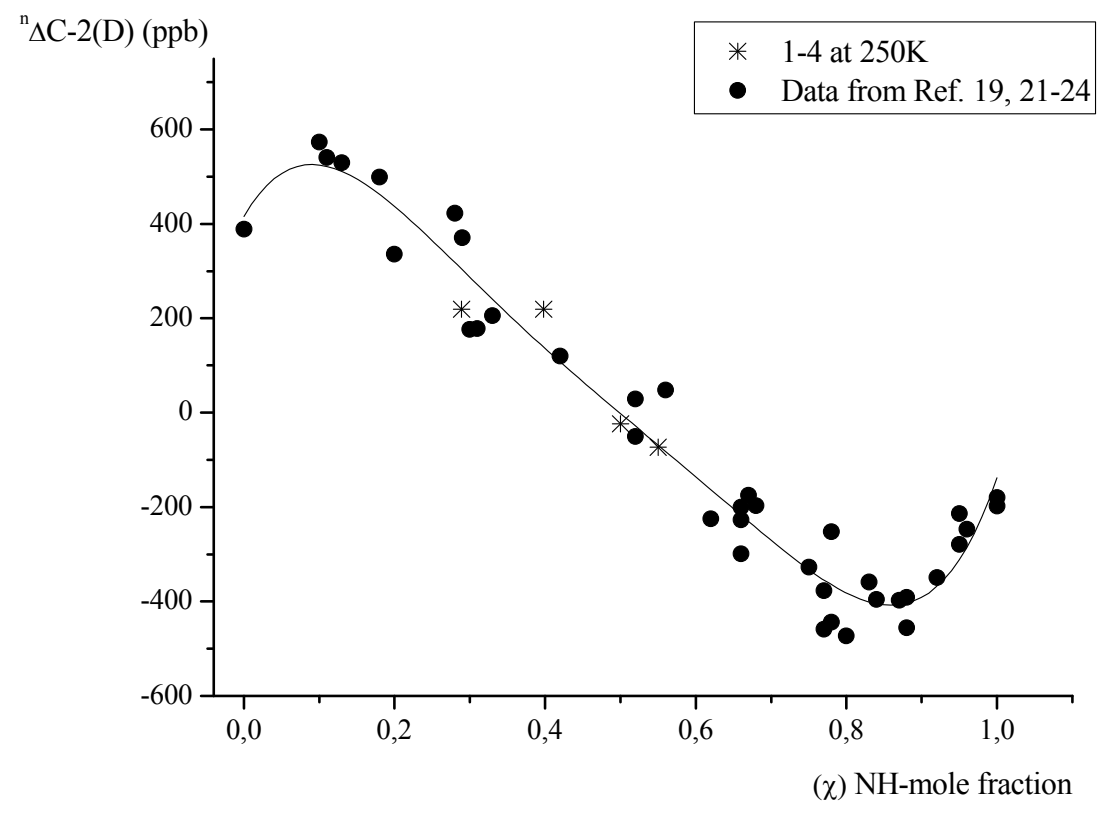

Values of $\Delta \mathrm{C}$-2(D) which are the most sensitive to the position of proton in the hydrogen bridge, are in the range from $\sim 250$ to $-75 \mathrm{ppb}$, so close to those observed for other derivatives of substituted salicylaldehydes in which the proton transfer equilibrium exists [24]. For the derivatives of L-valine, L-leucine and L-isoleucine at $230 \mathrm{~K}$ the mole fractions of $\mathrm{NH}$-form estimated from Figure 3, were close to $0.4-0.5$. The values of $\Delta \mathrm{C}$-2(D) observed for the L-threonine derivative indicated the presence of an equilibrium shifted towards the $\mathrm{OH}$-form ( $\chi$ equals $c a .0 .3) .{ }^{3} \mathrm{~J}(\mathrm{NH}, \mathrm{H})$ coupling constants as well as $\delta \mathrm{C}-2$ chemical shift values (Table 1 ) confirmed the equilibrium positions for compounds $\mathbf{1}-\mathbf{4}$. A lower 
mole fraction of the $\mathrm{NH}$-form for the L-threonine derivative and its small temperature dependence can be related to the presence of hydroxyl groups in the amino acid chain. A similar situation was observed for a Schiff base derivative of 2-hydroxynaphthaldehyde and L-threonine in which the proton transfer equilibrium was shifted towards the $\mathrm{OH}$-form [25], while the derivatives of other amino acids exist almost exclusively in the NH-form [20,21]. Although several attempts have been taken to measure a $\Delta \mathrm{C}$-2(D) value for compound 5 , it was not possible due to the broad and low intensity signal of the C-2 carbon, even at low temperatures. However, on the basis of the $\Delta \mathrm{C}-2$ (D) $v s . \Delta \mathrm{C}-1^{\prime}(\mathrm{D})$ relationship found for Schiff base derivatives of various salicylaldehydes and aliphatic amines [24] the $\Delta \mathrm{C}-1^{\prime}(\mathrm{D})$ value of $c a$. $-90 \mathrm{ppb}$ suggests that $\Delta \mathrm{C}-2$ (D) is close to $\sim 400 \mathrm{ppb}$, which is typical of the OH-form. The position of the $\delta \mathrm{C}-2$ signal at $c a .157 \mathrm{ppm}$ for the L-histidine derivative $\mathbf{5}$ is also typical of Schiff bases in which a proton transfer equilibrium does not exist [24]. Comparison of the chemical shifts of carbon C-2, $\Delta \mathrm{C}-2(\mathrm{D})$ as well as ${ }^{3} J(\mathrm{NH}, \mathrm{H})$ coupling constants in $\mathrm{CDCl}_{3}$ for the other studied Schiff bases 1-4 has also indicated that the presence of the L-histidine group shifted the position of the proton transfer equilibrium towards the pure $\mathrm{OH}$-form in 5. This shift of the equilibrium reveals that the conformation forced by the position of imidazole ring of L-histidine weakens the interactions between the COO- and $\mathrm{NH}^{+}$groups which stabilize the proton transferred form (Figure 4).

Figure 4. Influence of the imidazole ring on the conformation of 5.

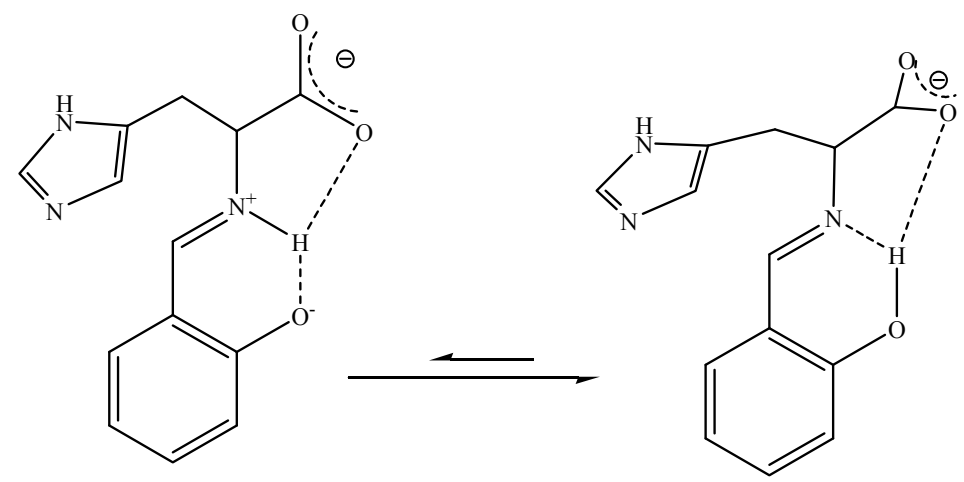

A similar situation was observed for Schiff base derivatives of L-phenylalanine and salicylaldehyde, in which the mole fraction of the $\mathrm{NH}$-form was close to 0.2 at $230 \mathrm{~K}$ [19]. However, for 5 this effect is particularly large. For compound 5 the $\delta \mathrm{C}-2$ values in range $c a .155-157 \mathrm{ppm}$ are typical of the pure $\mathrm{OH}$-form [24] while for other tetrabutylammonium salts of L-phenylalanine and various salicylaldehydes these values were in the 165-170 ppm range [19].

Deuterium isotope effects observed on the carboxylic carbon C-2' for compounds 1 and $\mathbf{4}$ (ca. $80 \mathrm{ppb}$ ) can be related to engagement of the $\mathrm{COO}^{-}$group in hydrogen bond [19].

The chemical shift values in DMSO solution of the C-2' carbons for the compounds studied ( $\delta 170-171 \mathrm{ppm})$ are close to those observed for lithium salts of amino acid Schiff base derivatives of 2-hydroxynaphthaldehyde, and indicate that the counter-ion is in the proximity of the carboxylic acid group. The $\delta \mathrm{C}-2^{\prime}$ values found in chloroform solution $(\delta 173-176 \mathrm{ppm})$ are closer to those observed for lithium salts of amino acid Schiff bases in $\mathrm{D}_{2} \mathrm{O}(178-180 \mathrm{ppm})$ [21]. DMSO has only a slight influence on the position of other signals. The influence of solvent on the position of equilibrium was small, judging by C-2 chemical shift values. Changes in chemical shifts related to the type of solvent used can be explained by small changes in the strength of the intermolecular hydrogen bond [20]. 
The length of the carbon chain of amino acid had a small influence on the position of the proton transfer equilibrium. For the L-valine, L-leucine and L-isoleucine derivatives the mole fractions of the $\mathrm{NH}$-form are similar. Even for the L-threonine derivative the position of equilibrium is close to those estimated for compounds 2-3. A similar situation was observed for the other Schiff base derivatives of amino acids and aromatic hydroxyaldehydes [19].

The characteristic IR absorption bands of amino acid ionic liquid-supported Schiff bases are presented in Table 2. In the IR spectra of the compounds studied the absorptions in the ca. 3500-2500 $\mathrm{cm}^{-1}$ range have been assigned to an intramolecularly bonded XH group. The $v(\mathrm{C}=\mathrm{N})$ band occurs at $\sim 1630 \mathrm{~cm}^{-1}$. The bands at $\sim 1610$ and $\sim 1370 \mathrm{~cm}^{-1}$ are assigned to $v\left(\mathrm{COO}^{-}\right.$sym. $)$and $v\left(\mathrm{COO}^{-}\right.$asym. $)[26,27]$.

Table 2. Selected IR brands of amino acids ionic liquid-supported Schiff bases $\mathbf{1}-\mathbf{5}\left(\mathrm{cm}^{-1}\right)$.

\begin{tabular}{ccccc}
\hline Comp. & $\boldsymbol{v}(\mathbf{X H})$ & $\boldsymbol{v}(\mathbf{C}=\mathbf{N})$ & $\boldsymbol{v}\left(\mathbf{C O O}^{-}\right)$as. & $\boldsymbol{v}\left(\mathbf{C O O}^{-}\right) \mathbf{s y m}$. \\
\hline (1) S-Thr & $3700-2700$ br. & 1630 & 1613 & 1377 \\
(2) S-Val & $3750-2700$ br. & 1630 & 1609 & 1368 \\
(3) S-Leu & $3700-2700$ br. & 1629 & 1606 & 1361 \\
(4) S-Ile & $3700-2875$ br. & 1629 & 1608 & 1361 \\
(5) S-His & $3500-2400$ br. & 1597 & 1597 ov. & 1391 \\
\hline
\end{tabular}

UV-Vis measurements were also performed for compounds $\mathbf{1 - 5}$. The UV-Vis bands of the studied amino acids ionic liquids-supported Schiff bases in ethanol and chloroform are presented in Table 3.

Table 3. UV-Vis bands of compounds $\mathbf{1}-\mathbf{5}$ in ethanol and chloroform solution (nm). In parentheses absorbance values.

\begin{tabular}{ccccc}
\hline Comp. & \multicolumn{2}{c}{ EtOH } & \multicolumn{2}{c}{ CHCl $_{3}$} \\
\hline \multirow{2}{*}{ (1) Sal-L-Thr } & $288(0.399)$ & $404(0.278)$ & $315(0.138)$ & $419(0.038)$ \\
& $317(0.447)$ & & $288(0.273)$ & $408(0.188)$ \\
(2) Sal-L-Val & $289(0.718)$ & $404(0.584)$ & $315(0.2)$ & \\
& $316(0.699)$ & & $291(0.478)$ & $410(0.315)$ \\
(3) Sal-L-Leu & $289(0.596)$ & $405(0.429)$ & $315(0.404)$ & \\
& $315(0.589)$ & & $289(0.27)$ & $408(0.175)$ \\
(4) Sal-L-Ile & $288(0.627)$ & $407(0.536)$ & $313(0.185)$ & n.o. \\
\hline (5) Sal-L-His & $315(0.572)$ & \multirow{2}{*}{$407(0.137)$} & $289(0.926)$ &
\end{tabular}

The UV-Vis spectra of all compounds show a low energy band at $\sim 410 \mathrm{~nm}$ and two high energy bands at $\sim 288$ and $\sim 315 \mathrm{~nm}$. On the basis of the results obtained for other derivatives of different aliphatic and aromatic amines these bands can be assigned to the $\mathrm{OH}$-form, while the one at $410 \mathrm{~nm}$ corresponds to the NH form [21,27-29]. The UV-Vis results indicate that the compounds studied exist in an equilibrium of NH- and $\mathrm{OH}$-forms, which is in agreement with the NMR results. For all compounds studied a more polar solvent shifted the proton transfer equilibrium towards the $\mathrm{NH}$-form [27-29]. Even for compound 5 which in a chloroform solution is in the pure $\mathrm{OH}-$ form, in an ethanol solution a small amount of the $\mathrm{NH}$-form was found.

The specific and molar rotation values are summarized in Table 4. No correlation between the type of amino acid and the molar rotation was observed. Molar rotation was stable in time. 
Table 4. Specific and molar rotation of amino acids ionic liquid-supported Schiff bases.

\begin{tabular}{ccc}
\hline Comp. & {$[\boldsymbol{\alpha}]_{\lambda}{ }^{\mathbf{T}}$} & {$[\mathbf{M}]_{\lambda}{ }^{\mathbf{T}}$} \\
\hline (1) Sal-L-Thr & +13.6 & +63.2 \\
(2) Sal-L-Val & +29.7 & +137.4 \\
(3) Sal-L-Leu & +4.9 & +23.4 \\
(4) Sal-L-Ile & +17.7 & +84.4 \\
(5) Sal-L-His & +0.7 & +50.1 \\
\hline
\end{tabular}

\subsection{ES MS}

ESI mass spectra of negative and positive ions were recorded for compounds 1-5. The positive region of ESI MS shows only one characteristic signal at $\mathrm{m} / \mathrm{z} 242$, assigned to tetrabutylammonium cations. Analysis of the ESI MS spectra of the compounds studied in the range of negative signals at low cone voltage confirmed the presence of the target compounds, evidenced by the $m / z=\mathrm{M}^{-}$signal. Increasing cone voltage used in subsequent experiments led to strong fragmentation of the molecules.

The spectra recorded for negative ions as a function of the cone voltage not only determine the fragmentation pathway of anions, but also characterize the stability of ions in the gas phase. The fragment ions observed for Schiff base compounds $\mathbf{1 - 5}$ are given in Scheme 1 .

Scheme 1. The ESI MS path of fragmentation of compounds 1-5.

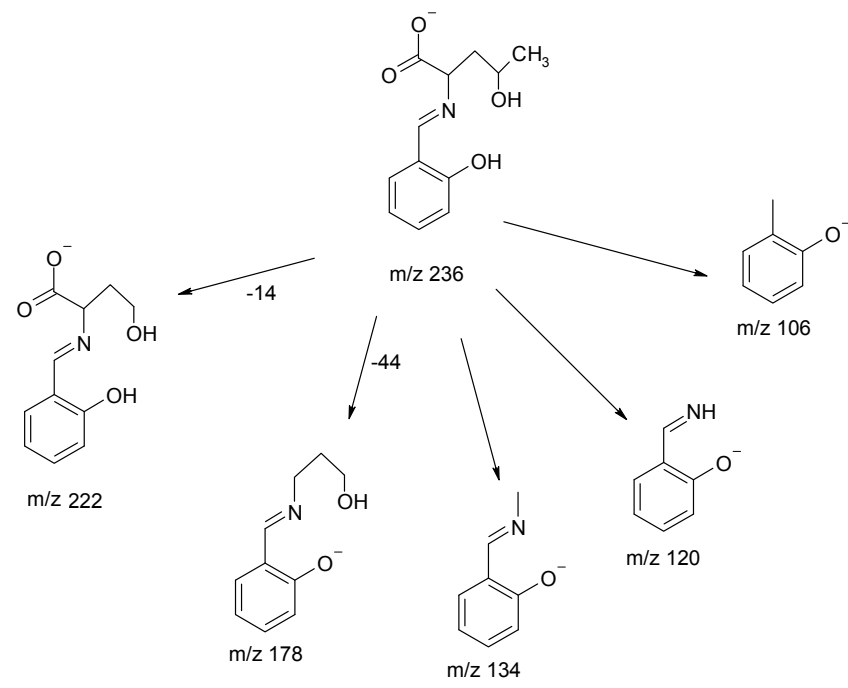

1

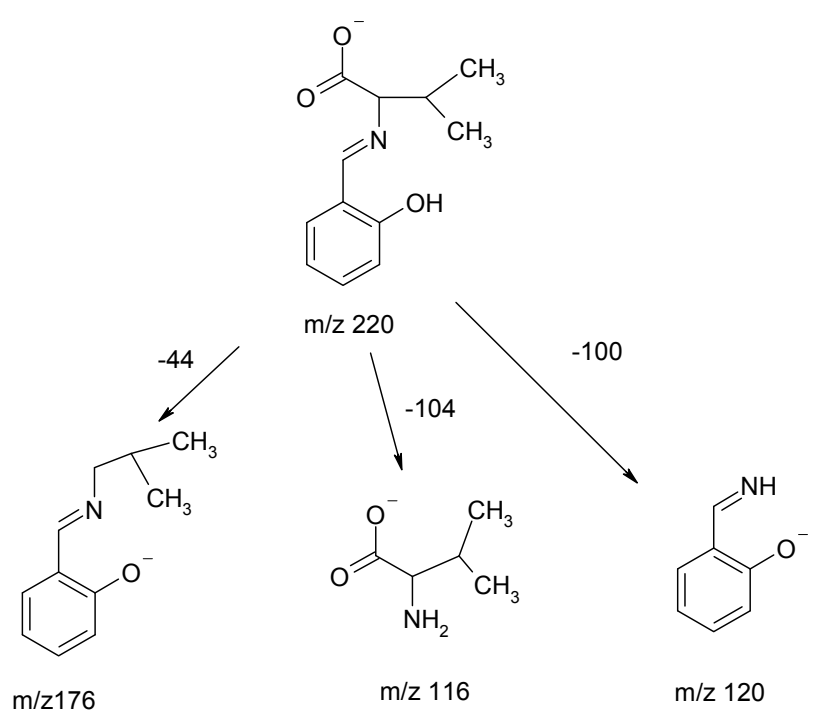

2 
Scheme 1. Cont.

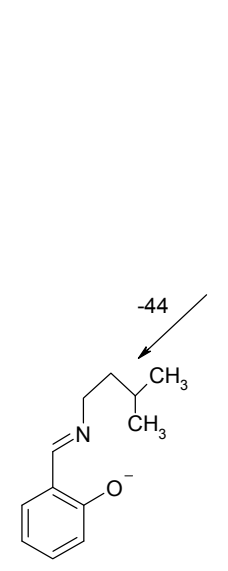

$\mathrm{m} / \mathrm{z} 190$
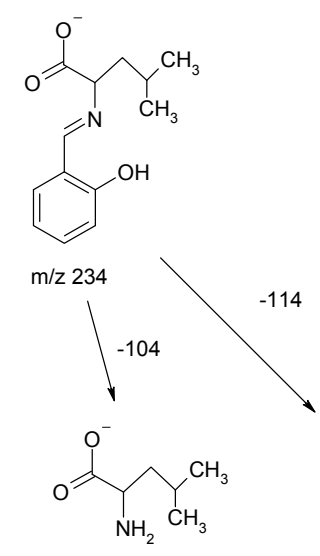

$\mathrm{m} / \mathrm{z} 130$

3



$\mathrm{m} / \mathrm{z} 190$
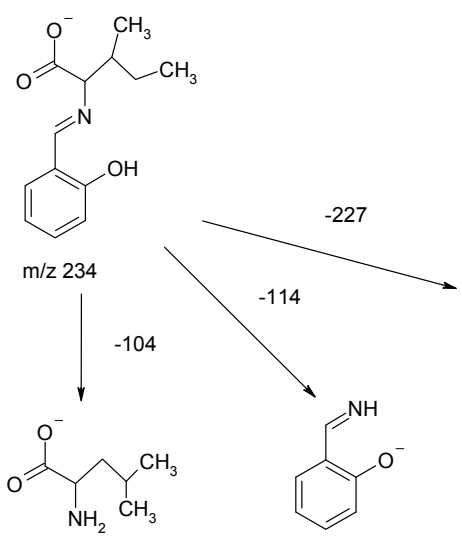

$\mathrm{m} / \mathrm{z} 120$

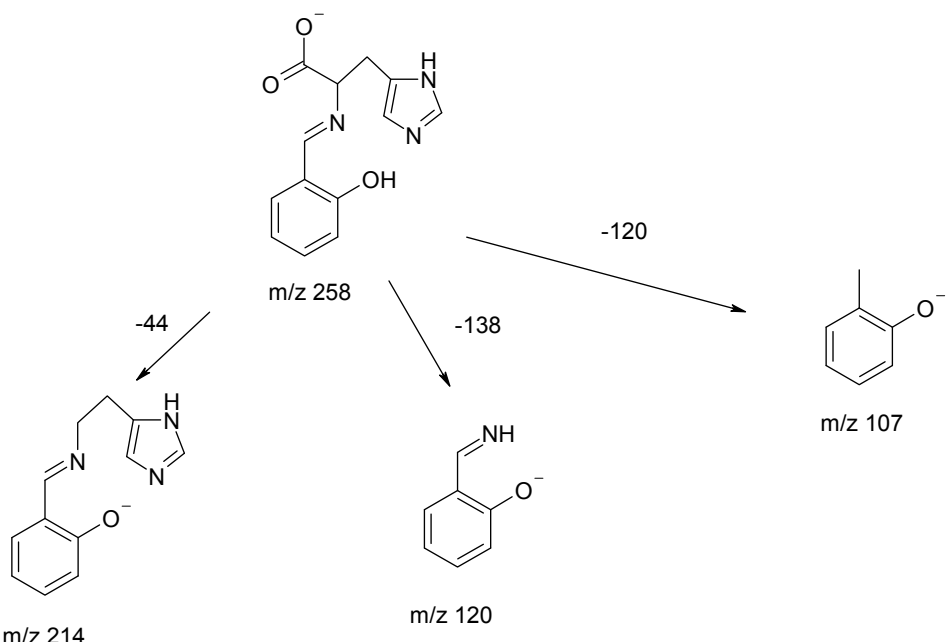

5

For compounds 1-5 a few specific processes or ions were observed. The molecular ions as the precursor ionic species $\mathrm{P}^{-}$eliminated a $\mathrm{CO}_{2}$ molecule in the decarboxylation reactions [30]. The characteristic signals at $\mathrm{m} / \mathrm{z} 107$ and 120 observed for the studied compounds appear as a result of elimination of the amino acid fragment. The specific fragments characteristic of various Schiff bases are determined by the structure of a given amino acid [30-33].

The negative ESIMS spectra were recorded as a function of cone voltage in 10-180 V range. The correlations of relative ion abundance $v s$. cone voltage for compounds $\mathbf{1 - 5}$ are collected in Figure 5.

The dependence of ion abundance on cone voltage is determined by the ions' stability in the gas phase and this stability is responsible for the relative intensity of the $\mathrm{m} / \mathrm{z}$ signals at a constant cone voltage. The stabilities of both precursor and fragment ions depend on the structure of the amino acid Schiff bases. Throughout the cone voltage range tested, a high instability of negative ions in the gas phase was noted. 
Figure 5. The correlations of relative ion abundance $v s$. cone voltage for compounds: 1 (a); compound 2 (b); compound $\mathbf{3}$ (c); compounds $\mathbf{4}$ (d) and compound $\mathbf{5}$ (e).

(a)

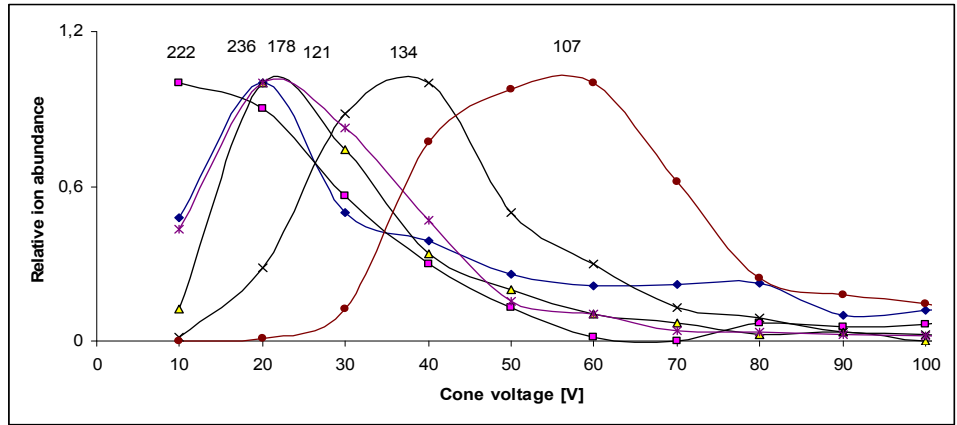

(b)

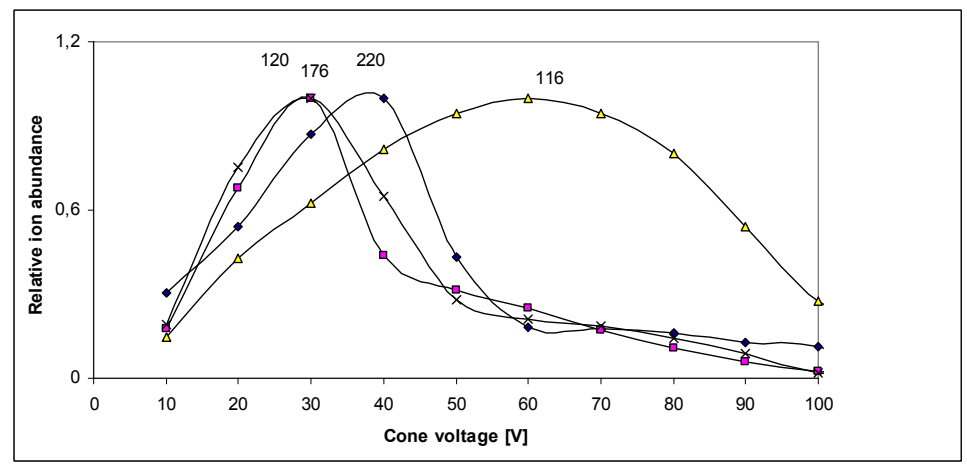

(c)

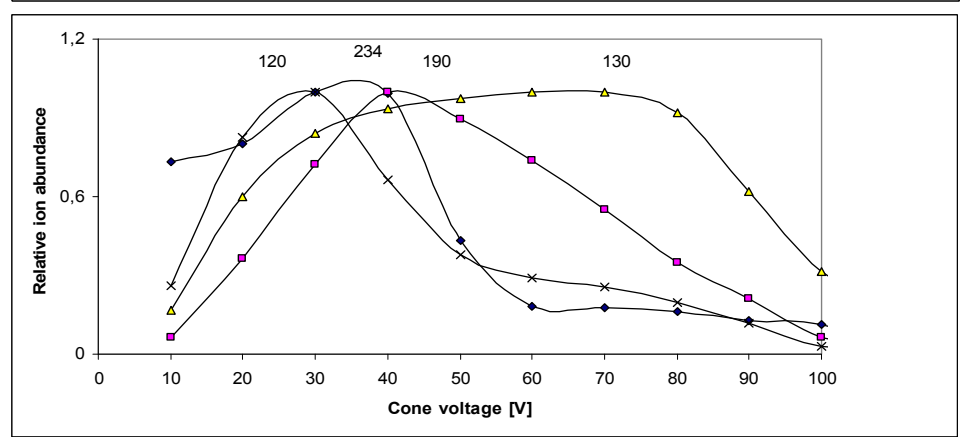

(d)

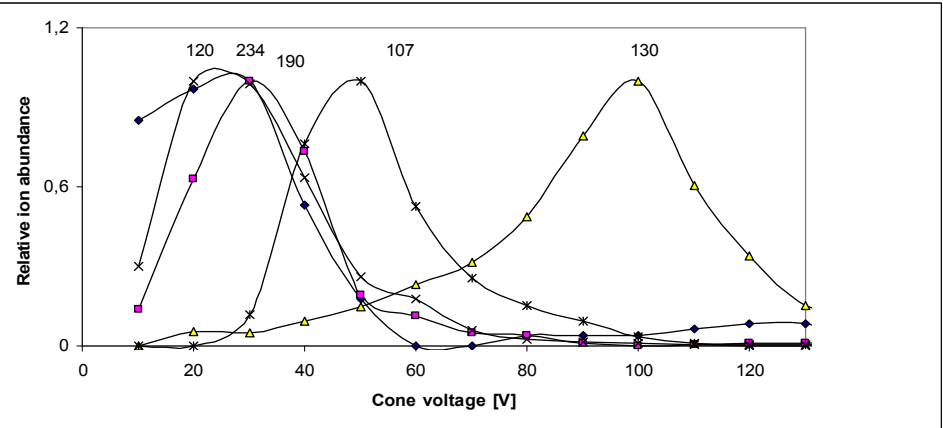

(e)

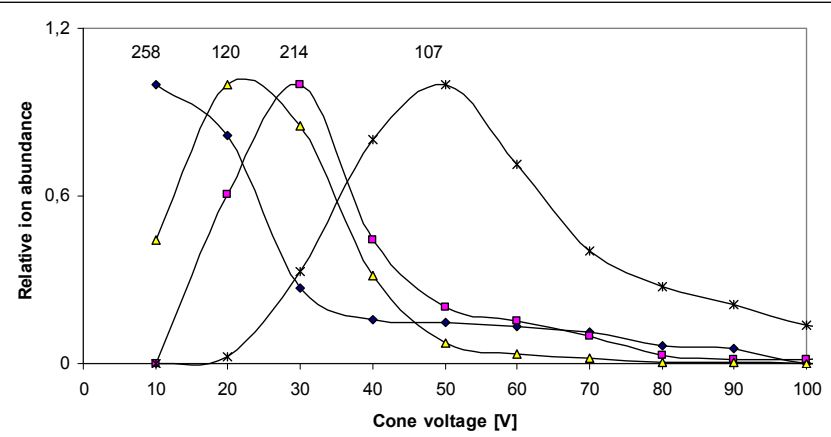




\section{Experimental}

\section{General}

Tetrabutylammonium salts of amino acids were prepared by the reaction of a slight molar excess of amino acid dissolved in water and $40 \%$ aqueous tetrabutylamonium hydroxide solution (Scheme 2a). After the reaction, water was removed under reduced pressure [34]. The intermediate product was dried in a vacuum oven at $60{ }^{\circ} \mathrm{C}$ under a pressure of 2 mbar for $24 \mathrm{~h}$. Amino acid ionic liquid-supported Schiff bases were synthesized by condensation of tetrabutylammonium salts of amino acids with salicylaldehyde according to the procedure described elsewhere (Scheme 2b) [19]. The reaction was carried out in absolute ethanol. After completion of the reaction, the solvents were removed under reduced pressure. The product in the form of yellow oil was dried under reduced pressure. Compound 5 was obtained in the form of yellow needles (melting point $74{ }^{\circ} \mathrm{C}$ ). All compounds studied were stable in DMSO, ethanol and chloroform, although in chloroform solutions after $c a$. 1 h some symptoms of compound $\mathbf{5}$ decomposition were observed.

Scheme 2. Synthesis of amino acid ionic liquid supported Schiff bases.

a)

b)<smiles>[R]C(N)C(=O)O</smiles>

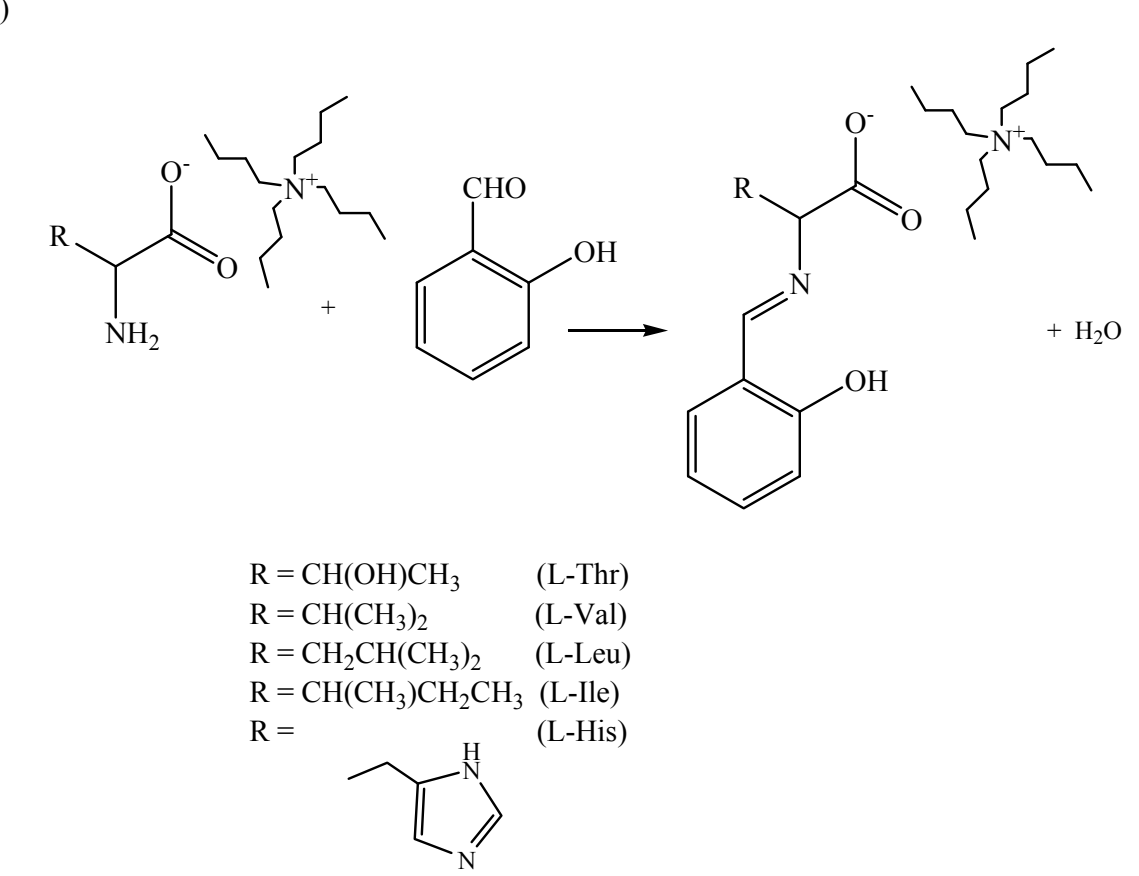

The ${ }^{1} \mathrm{H}$ and ${ }^{13} \mathrm{C}$-NMR spectra were recorded on a Bruker DPX-400 spectrometer operating at 100.62 $\mathrm{MHz}\left({ }^{13} \mathrm{C}\right)$ and $400.13 \mathrm{MHz}\left({ }^{1} \mathrm{H}\right)$, respectively. Typical spectral parameters were used for ${ }^{13} \mathrm{C}$-NMR: spectral width $24 \mathrm{kHz}$, number of data points $65.5 \mathrm{~K}, 1.46 \mathrm{~Hz}$ per point digital resolution, acquisition time $1.37 \mathrm{~s}$, relaxation delay $1 \mathrm{~s}$, pulse width $9.2 \mu \mathrm{s}$, number of scans $1,000-8,000$; for 
${ }^{1} \mathrm{H}-\mathrm{NMR}$ : spectral width $12 \mathrm{kHz}$, number of data points $65.5 \mathrm{~K}, 0.488 \mathrm{~Hz}$ per point digital resolution, acquisition time $4.09 \mathrm{~s}$, relaxation delay $1 \mathrm{~s}$, pulse width $7.8 \mu \mathrm{s}$, number of scans 16 . The chemical shifts were referred to TMS as internal standard. Typical concentration of the samples was $0.1 \mathrm{M}$. The temperature was maintained and measured with Eurotherm BV-T 2000 to an accuracy of $1 \mathrm{~K}$. Deuteration of the compounds was achieved by dissolving the sample in $\mathrm{CH}_{3} \mathrm{OD}$ followed by evaporation under reduced pressure.

The diffuse reflectance FT IR spectra were measured on Nicolet 380 Thermo Electron Corporation on $\mathrm{KBr}$ pellets. UV-Vis absorption spectra were measured using a Spectroquant ${ }^{\circledR}$ Pharo 300 Spectrophotometer from Merck to the accuracy of $\pm 1 \mathrm{~nm}$ in a $10 \mathrm{~mm}$ quartz cell. The concentration of solutions for all compounds was in range $10^{-4}-10^{-5}$. The absolute ethanol was purchased from EUROCHEM, spectral grade chloroform from POCh.

NMR, FT-IR and UV-Vis spectra are available as supporting information.

The specific rotation of new amino acids ionic liquids-supported Schiff bases was investigated on Polarymetr Autopol IV from Rudolph Research Analytical. Mass spectra (MS) were recorded on ZQ Waters/Micromass Mass Spectrometer (Manchester, UK) with quadrupole analyser with the following parameters used: source potential ESI on capillaries: $3 \mathrm{kV}$; voltage on focal pla: $0.5 \mathrm{~V}$; voltage on extract: $4 \mathrm{~V}$; the cone voltage (cv): $30 \mathrm{~V}$, ion fragmentation was examined with 10-180 V (cv); source temperature: $120{ }^{\circ} \mathrm{C}$; evaporation temperature: $300{ }^{\circ} \mathrm{C}$; nitrogen was used as a spraying and drying gas at the flow rate of 80 and $300 \mathrm{~L} \mathrm{~h}^{-1}$.

ESI mass spectra of negative and positive ions of compounds 1-6 were recorded in MCA mode (Multi Channel Acquisition) in $m / z=100-1,000$ interval. The typical spectrum obtained was the average of 10 scans with $0.6 \mathrm{~s}$ time interval. The solutions studied were introduced to the ionization source (at the flow rate $40 \mu \mathrm{L} \mathrm{min}{ }^{-1}$ ) through a Harvard Scientific pump. All the solutions subjected to ESI MS were prepared in methanol.

\section{Conclusions}

Spectroscopic studies have shown that the tetrabutylammonium salts of amino acid Schiff base derivatives of salicylaldehydes 1-4 exist in tautomeric equilibrium. The position of proton transfer equilibrium was shifted towards the $\mathrm{NH}$-form at a mole fraction above 0.5 for the derivatives of L-valine, L-leucine and L-isoleucine at low temperatures in a chloroform solution. For the L-threonine derivative 5 the equilibrium was shifted towards the $\mathrm{OH}$-form, while the L-histidine derivative existed in chloroform and DMSO solutions exclusively in the $\mathrm{OH}$-form. It was confirmed that the proton transferred form was stabilized by a bifurcated intramolecular hydrogen bond. The presence of the imidazole ring weakens the interactions between the $\mathrm{COO}$ - and $\mathrm{NH}$ groups, which stabilizes the proton transferred form.

\section{Supplementary Materials}

Supplementary materials can be accessed at: http://www.mdpi.com/1420-3049/18/5/4986/s1. 


\section{Acknowledgments}

The authors thank Teresa Dziembowska for helpful discussions. Z.R. and G.S thank the Polish Ministry of Science and Higher Education for financial support under Grants No. NN 204338237 in the years 2009-2013.

\section{References}

1. Stark, A.; Seddon, K.R. Ionic Liquids. In Chemical Technology and the Environment, 1st ed.; Kirk-Othmer, Ed.; Wiley-Interscience: New York, NY, USA, 2007; Volume 1, pp. 308-392.

2. Earle, M.; Seddon, K. Ionic liquids. Green solvent for the future. Pure App. Chem. 2000, 72, 1391-1398.

3. Dramska, A.; Antoszczyszyn, M.; Janus, E. Reakcja Dielsa i Aldera w cieczach jonowych z dodatkiem trifluorometanosulfonianów skandu i litu jako katalizatorów. Przem. Chem. 2006, 85, 47-49.

4. Pinkert, A.; Marsh, K.N.; Pang, S.; Staiger, M.P. Ionic Liquids and Their Interaction with Cellulose. Chem. Rev. 2009, 109, 6712-6728.

5. Zhou, T.; Chen, L.; Ye, Y.; Chen, L.; Qi, Z.; Freund, H.; Sundmacher, K. An Overview of Mutual Solubility of Ionic Liquids and Water Predicted by COSMO-RS. Ind. Eng. Chem. Res. 2012, 51, 6256-6264.

6. Keskin, S.; Kayrak-Talay, D.; Akman, U.; Hortaçsu, Ö. A review of ionic liquids towards supercritical fluid applications. J. Supercrit. Fluids 2007, 43, 150-180.

7. Mallakpour, S.; Dinari, M. Ionic Liquids as Green Solvents: Properties and Prospects. In Green Solvents II-Properties and Applications of Ionic Liquids, 1st ed.; Mohammad A., Inamuddin, D., Eds.; Springer: Dordrecht, The Netherlands, 2012; Chapter 1, pp. 1-32.

8. Domínguez de Maria, P. Ionic Liquids: Deffinitions, Applications, and Context for Biotransformations and Organocatalysis. Ionic Liquids in Biotransformation and Organocatalysis: Solvents and Beyond, 1 st ed; Domínguez de Maria P., Eds.; John Wiley \& Sons Inc.: New York, NY, USA, 2012; Chapter 1, pp. 1-14.

9. Hu, S.; Jiang, T.; Zhang, Z.; Zhu, A.; Han, B.; Song, J.; Xie, Y.; Li, W. Functional ionic liquid from biorenewable materials: Synthesis and application as a catalyst in direct aldol reactions. Tetrahedron Lett. 2007, 48, 5613-5617.

10. Payagala, T.; Armstrong, D.W. Chiral Ionic Liquids: A Compendium of Syntheses and Applications (2005-2012). Chirality 2012, 24, 17-53.

11. Khungar, B.; Rao, M.S.; Pericherla, K.; Nehra, P.; Jain, N.; Panwar, J.; Kumar, A. Synthesis, characterization and microbiocidal studies of novel ionic liquid tagged Schiff bases. C. R. Chimie 2012, 15,669-674.

12. Ouadi, A.; Gadenne, B.; Hesemann, P.; Moreau, J.J.E.; Billard, I.; Gaillard, C.; Soufiane, M.; Moutiers, G. Task-Specific Ionic Liquids Bearing 2-Hydroxybenzylamine Units: Synthesis and Americium-Extraction Studies. Chem. Eur. J. 2006, 12, 3074-3081. 
13. Chan-Hout, M.; Sharif, S.; Tolstoy, P.M.; Toney, M.D.; Limbach, H.H. NMR Studies of Stability, Protonation Site, and Tautomerism of ${ }^{13} \mathrm{C}$ - and ${ }^{15} \mathrm{~N}$-Labeled Aldimines of the Coenzyme Pyridoxal 5'-Phosphate in Water. Biochemistry 2010, 49, 10818-18830.

14. Christen, P.; Metzler, D.E. Transaminases, 1st ed.; Wiley \& Sons: New York, NY, USA, 1985; pp. 37-101.

15. Li, B.; Li, Y.-Q.; Zheng W.-J.; Zhou, M.-Y. Synthesis of ionic liquid-supported Schiff bases. Arkivoc 2009, XI, 165-171.

16. Li, B.; Zheng, Y.-Q.; Li, J. A novel ionic liquid-supported Schiff base ligand applied in the Pd-catalyzed Suzuki-Miyaura coupling reaction Arkivoc 2010, IX, 163-170.

17. Ohlin, C.A.; Dyson, P.J.; Laurenczy, G. Carbon monoxide solubility in ionic liquids: determination, prediction and relevance to hydroformylation. Chem.Commun. 2004, 2004, 1070-1071.

18. Vidiš, A.; Ohlin, C.A.; Laurenczy, G.; Küsters, E.; Sedelmeier, G.; Dyson, P.J. Rationalisation of Solvent Effects in the Diels-Alder Reaction Between Cyclopentadiene and Methyl Acrylate in Room Temperature Ionic Liquids. Adv. Synth. Catal. 2005, 347, 266-274.

19. Rozwadowski, Z. Deuterium isotope effect on $13 \mathrm{C}$ chemical Shift of tetrabutylammonium salts of Schiff bases amino acids. Magn. Reson.Chem. 2006, 44, 881-886.

20. Rozwadowski, Z.; Ambroziak, K.; Szypa, M.; Jagodzińska, E.; Spychaj, S.; Schilf, W.; Kamieński, B. The ${ }^{15} \mathrm{~N}$ and ${ }^{13} \mathrm{C}$-NMR study of Schiff bases derivatives of amino acids and their lithium salts in solid state and DMSO. J. Mol. Struct. 2005, 734, 137-142.

21. Rozwadowski, Z. Deuterium isotope effects on ${ }^{13} \mathrm{C}$ chemical shifts of lithium salts of Schiff bases amino acids. J. Mol. Struct. 2006, 753, 127-131.

22. Dziembowska, T.; Hansen, P.E.; Rozwadowski, Z. Studies based on deuterium isotope effect on ${ }^{13} \mathrm{C}$ chemical shifts. Prog. Nucl. Magn. Reson. Spectrosc. 2004, 45, 1-29.

23. Rozwadowski, Z. NMR Studies of optically active Schiff bases. Ann. Rep. NMR Spectrosc. 2011, 74, 125-180.

24. Rozwadowski, Z.; Majewski, E.; Dziembowska, T.; Hansen, P.E. Deuterium isotope effects on ${ }^{13} \mathrm{C}$ chemical shifts of intramolecularly hydrogen-bonded Schiff bases. J. Chem. Soc. Perkin Trans. 2 1999, 1999, 2809-2817.

25. Özcan, Y.; Ide, S.; Şakiyan, I.; Logoglu, E. Structure and characterization of $N$-(2-hydroxy-1naphthylidene)threonine. J. Mol. Struct. 2003, 658, 207-213.

26. Przybylski, P.; Pyta, K.; Ratajczak-Sitarz, M.; Katrusiak, A.; Brzezinski, B. X-ray, FT-IR, ESI MS and PM5 studies of Schiff base of gossypol with allylamine and its complexes with alkali metal cations and perchlorate anion. Struct. Chem. 2008, 19, 983-995.

27. Rubčić, M.; Užarević, K.; Halasz, I.; Bregović, N.; Mališ, M.; Dilović, I.; Kokan, Z.; Stein, R.S.; Dinnebier, R.E.; Tomišić, V. Desmotropy, Polymorphism, and Solid-State Proton Transfer: Four Solid Forms of an Aromatic o-Hydroxy Schiff Base. Chem. Eur. J. 2012, 18, 5620-5631.

28. Güngör, Ö.; Gürkan, P. Synthesis and spectroscopic properties of novel asymmetric Schiff bases. Spectrochim. Acta A 2010, 77, 304-311.

29. Herzfeld, R.; Nagy, P. Studies of the Solvent Effect Observed in the Absorption Spectra of Certain Types of Schiff Bases. Curr. Org. Chem. 2001, 5, 373-394. 
30. Zeng, Q.-L.; Chen, W-Z.; Zhao, Y.-F. Electrospray ionization mass spectral fragmentation study of amino acid derived oxovanadium Schiff base complexes and (oxo)-peroxovanadium Schiff base complexes. Inter. J. Mass Spectr. 2007, 262, 161-167.

31. Gilbert, W.C.; Taylor, L.T.; Dillard, J.G. Mass-spectrometric study of polydentate Schiff-base coordination compounds. I. Cobalt(II), nickel(II), and copper(II) complexes of Salen [bis(salicylidene)ethylenediamine] and Oaben [bis(o-aminobenzylidene) ethylenediamine]. J. Am. Chem. Soc. 1973, 95, 2477-2482.

32. Dubey, R.K.; Mariya, A.; Mishra, S.K. Synthesis and spectral (ir, nmr, fab-ms and xrd) characterization of lanthanide complexes containing bidentate schiff base derived from sulphadiazine and o-vanillin. Int. J. Basic Appl. Chem. Sci. 2011, 1, 70-78.

33. Salmann, S.R.; Saleh, N.A.I. Mass Spectral Study of Tautomerism in Some Schiff Bases. Spectrosc. Lett. 1998, 31, 1179-1189.

34. Allen, C.R.; Richard, P.L.; Ward, A.J. van de Water, L.G.A.; Masters, A.F.; Maschmeyer, T. Facile synthesis of ionic liquids possessing chiral carboxylates. Tetrahedron Lett. 2006, 47, 7367-7370.

Sample Availability: Samples of the compounds 1-4 are available from the authors.

(C) 2013 by the authors; licensee MDPI, Basel, Switzerland. This article is an open access article distributed under the terms and conditions of the Creative Commons Attribution license (http://creativecommons.org/licenses/by/3.0/). 